\title{
What Are Good Leaders Made Of? Finnish School Children's Descriptions of Leadership
}

\author{
Sanna Hyvärinen \\ University of Lapland \\ PO Box 122, 96101 Rovaniemi, Finland \\ E-mail: Sanna.Hyvarinen@rovaniemi.fi \\ Satu Uusiautti (Corresponding author) \\ University of Lapland \\ PO Box 122, 96101 Rovaniemi, Finland \\ E-mail: Satu.Uusiautti@ulapland.fi \\ Kaarina Määttä \\ University of Lapland \\ PO Box 122, 96101 Rovaniemi, Finland \\ E-mail: Kaarina.Maatta@ulapland.f
}

Received: Nov. 1, 2017 Accepted: Nov. 30, 2017 Published: November 30, 2017

doi:10.5296/jse.v7i4.12200 URL: https://doi.org/10.5296/jse.v7i4.12200

\begin{abstract}
The purpose of this research was to analyze Finnish students' descriptions of good leaders and leadership. The study had two research questions: (1) What kinds of characteristics does a good leader have according to Finnish students' perceptions and (2) how do the students describe the emphases of leadership activities? This was a qualitative study that applied the narrative research approach. The data consisted of essays written by 38 sixth-graders from one Finnish school. The data collection method used empathy-based frame stories to prompt essays. The main characteristics of a good leader were friendliness, diligence and enthusiasm, and deliberation and determination. Three emphases in leadership activities could be found in the essays: decision-making and responsibility for results, caring, and enjoyment of the
\end{abstract}




\section{Macrothink}

Journal of Studies in Education

ISSN 2162-6952

2017, Vol. 7, No. 4

leader's work. The study contributes new viewpoints to the authentic leadership theory and less studied perspectives in the field of leadership studies in general.

Keywords: leadership, authentic leadership, narrative research, the method of empathy-based stories (MEBS) 


\section{Introduction}

Today's world calls for good leadership and entrepreneurship. Leaders should be able to promote the productivity and well-being in workplaces, and therefore, leadership is a common topic in everyday discourse and in scientific research. Conceptions of good leadership have changed in the past, and the over-100-year-long history of leadership research shows that there is not a common framework or definition to leadership. The field of research is somewhat fragmented (Ladkin, 2010; Northouse, 2013; Peele, 2005; Yuk1, 2010).

Along with new leadership theories, especially the concept of authentic leadership and its essence have gained plenty of attention in the 21 st-century leadership research (see e.g., Gardner et al., 2011; Gill \& Caza, 2015; Ladkin \& Taylor, 2010; Yukl, 2010). The roots of the theory lean on the positive psychological viewpoint of leadership (see e.g., Avolio \& Gardner, 2005; Seligman, 2011; Seligman, Steen, Park, \& Peterson, 2005). In this leadership theory, authenticity refers to the genuine reflection and ownership of one's experiences-including thoughts, feelings, needs, and beliefs — as well as action according to them (Harter, 2002).

The characteristics of a good leader have been studied for ages. Naturally, studies in various organizations and contexts always provide a different description of the ideal leadership (see e.g., Gardner et al., 2011; Gill \& Caza, 2015; Ladkin, 2010; Northouse, 2013; Peele, 2005; Yukl, 2010). Usually, leaders have been the research targets but also employees have been asked to evaluate their leaders' and managers' leadership skills in various workplaces (e.g., Busser, 2015). The purpose of this study is to analyze Finnish students' perceptions of leadership. By researching children's leadership conceptions (see also Bigler, Arthur, Hughes, $\&$ Patterson, 2008), it is possible to find new kinds of viewpoints to the essence of leadership and expectations toward leadership. What children consider as good leadership action and behaviors provides a new and less studied viewpoint to leadership studies. The way we perceive leadership and the leader's work comes from our childhood homes through different examples, values, attitudes, models, and future goals (Allen, Hauser, Bell, \& O'Connor, 1994; Berscheid, 2002; Bradley \& Corwyn, 2002; Hartman \& Harris, 1992; Hyvärinen \& Uusiautti, 2014; Madsen, 2007; Uusiautti \& Määttä, 2015) and are molded also through other early learning experience (Hyvärinen, Uusiautti, \& Määttä, 2014; Li et al., 2007; Lord \& Hall, 2005; Murphy \& Johnson, 2011). Although school contexts are places of student's socialization and educational leadership practiced at school provide examples of leadership for children that differ from those of other institutions (e.g., Hallinger \& Heck, 2011; Määttä \& Uusiautti, 2012), children also meet leaders from various organizational contexts. The image of leadership as presented in media has its own role in the way we see leaders (see e.g., Aubrey \& Harrison, 2004; Hoffner, 1996).

Children's conceptions of leadership may be unrealistic and lack actual experiences and attitudes that adults have about leadership. Despite that or due to that, they might reveal the actual core of leadership. In Anderson's fairytale, a child sees that the emperor does not have any clothes. Children's insights can bring new viewpoints to leadership as well! 


\section{Theoretical Background}

Despite the various theoretical emphases and varied leadership contexts, leadership consists of certain core elements. Leaders are expected to handle both management and leadership. The former refers to the organizational goals and aspired outcomes, and leading toward that specific vision. The latter is about people management: how to get employees work toward to common goal and vision, how to motivate, encourage, and spur them (Northouse, 2013; Syväjärvi \& Vakkala, 2012; Yukl, 2010). Leadership is a multi-faceted and complex phenomenon (Ladkin, 2010).

The latest leadership research has been focused on the so-called authentic leadership. It has been characterized in many ways (see e.g., Gardner et al., 2011; Gill \& Caza, 2015) and the concept is still young and forming (see Gardner et al., 2011; Ladkin \& Taylor, 2010; Nyberg \& Sveningsson, 2014; Yukl, 2010). Among others, the following four elements have been included in the definition of authentic leadership: self-awareness, relational transparency, balanced processing, and internalized moral perspective (see e.g., Avolio \& Gardner, 2005; Gardner et al., 2011; Gill \& Caza, 2015). Self-awareness refers to the leaders' ability to recognize their own strengths and weaknesses and how they influence other people. Self-awareness increases through feedback giving and receiving. Relational transparency consists of open distribution of information and expression of one's thoughts and feelings openly and appropriately. Relational transparency increases employees' trust in expressing their own opinions and viewpoints at the workplace. Balanced processing refers to leaders' skill of analyzing all information objectively before decision-making. Therefore, it also consists of the ability to recognize, hear, and discuss viewpoints that are different to those of leader's own. Internalized moral perspective means self-control and regulation that makes it possible to follow one's own moral values regardless of the pressure from one's environment. Authentic leaders have a strong sense of right and wrong. According to Cianci, Hannah, Avolio, and Walumbwan (2014), it is a moral compass that also employees can trust and follow. Authentic leaders genuinely try to understand their own leadership and themselves as leaders in order to serve others efficiently (cf., Russel \& Stone, 2002). The four aforementioned elements have provided a way to analyze authentic leadership, even though the elements can be critically questioned (see e.g., Hannah, Avolio, \& Walumbwa, 2014). According to the current opinion, more research is needed about the elements of authentic leadership (see Gardner et al., 2011; Gill \& Caza, 2015). On the other hand, research on authentic leadership may provide new ways of learning and understanding the development of leadership (see e.g., Sparrowe, 2005) and many dimensions of leadership practices (see e.g., Dodge, Ospina, \& Foldy, 2005; Fleming, 2001).

Leadership theories' purpose is to define the essence of good leadership and its elements. In this study, we describe how schoolchildren perceive leadership and of what kinds of characteristics they assume it consists. Their conceptions give one, interesting and new depiction of leadership, and provide perhaps a glimpse of tomorrow's leadership.

\section{Method}

The purpose of this study is to analyze Finnish students' descriptions of a good leader. The 
following research questions were set for this research:

(1) What kinds of characteristics does a good leader have according to Finnish students' perceptions?

(2) How do the students describe the emphases of leadership activities?

The students' descriptions were analyzed by contrasting them with the authentic leadership theory. Methodologically, this study applied the narrative research approach (see e.g., Heikkinen, 2010; Hänninen, 2003; Lieblich, Tuval-Mashiach, \& Zilber, 1998; Polkinghorne, 1995; Riessman, 2008) located in the qualitative research paradigm (Polkinghorne, 1995). Narrative research represents an approach that focuses on narratives as ways of transmitting and constructing information. The relationship between research and narrative can be viewed from two main perspectives: the research data can be narratives but research also produces a narrative about the world (Heikkinen, 2010). Narrative research can refer to the information process as such, way of knowing, and the nature of information when it represents constructivism (Bruner, 1986, 1987, 1991; Heikkinen, 2010; Lieblich, Tuval-Mashiach, \& Zilber, 1998; Riessman, 2008). In this research, the narrative approach covered not only the methodological choices of data collection but also data analyses thus forming a framework for the study as a whole (Heikkinen, 2010).

Narrative research provides an opportunity to peep into the children's world and understand their experiences (Kyrönlampi, Uusiautti, \& Määttä, 2014). When students write narratives, they might be able to express themselves more openly than in an interview situation in which the adult always somehow defines the child's position (Engel, 1995). Children's perceptions are difficult to reach because the researcher should be able to detach from adult-centered research world, give voice to the child and hear the child's perception of the world (Mahon, Glendinning, Clarke, \& Craig, 1996). This was also one of the challenges in this study, too: how to find and reach the children's experiences and opinions? In all phases of the study, it was important to bear in mind the pursuit of hearing the children and respecting them as research participants (Kyrönlampi, Uusiautti, \& Määttä, 2014).

In this study, the research data were collected in one Finnish school among sixth-graders $(\mathrm{N}=$ 38, 19 girls and 19 boys, aged 12-13). The data collection method was the method of empathy-based stories (MEBS) which refers to short essays prompted by a frame story that the researcher has conducted (Eskola, 1997, 1998, 2010). The method was considered suitable in this study because sixth-graders are used to write essays at school and they could probably express their conceptions more freely by writing than, for example, by participating in an interview.

The frame story is an orientation to the topic, and the students were to write a small story based on the images they had. In these stories, the students continue the frame story or describe what had happened before the situation described in the frame story. Usually, there are two or more frame stories in which one or two items have changed (e.g., a positive and a negative event). The interest is in the variation between stories and the researcher can analyze what changes in the written stories when a core element in the frame story is changed (Eskola, 
1997, 1998, 2010; see also Ikonen, 2013).

This study applied two frame stories. The variation occurred in the way the leader's day had gone (a successful day and a failure). The students were asked to take Leader Smith's position and continue the stories:

Leader Smith comes home and is very happy. Work day had been good, things had gone well, and employees had been happy. Use your imagination and write a story about Leader Smith's workday. What had happened during Leader Smith's day? Where is Leader Smith working? What had made Leader Smith happy about leader's work? Why is Leader Smith a good leader? You have 30 minutes to write the story.

Leader Smith comes home and is very chagrined. Work day had been bad, things had gone lousily, and employees had been unhappy. Use your imagination and write a story about Leader Smith's workday. What had happened during Leader Smith's day? Where is Leader Smith working? What had made Leader Smith unhappy about leader's work? Why is Leader Smith a bad leader? You have 30 minutes to write the story.

This prompt had the emphasis on the workday instead, for example, to a leader's whole career because of two reasons: (1) considering the research participants' age, the assumption was that children would find it more concrete and easier to describe leadership and leaders' actions by thinking about a good or a bad day, and (2) as the method was a frame story to be continued, a very concrete and specific starting (prompt) had to be composed to help participants write. However, the last question in the prompt (Why is Leader Smith a good/bad leader?) was also added to direct the children's thoughts to a wider perspective, too.

The students were not aware of the two different frame stories. The frame stories were distributed to students by using their alphabetical order so that both frame stories had equal number of students (girls and boys) writing them. However, since two students were absent, the eventual data had unequal number of positive $(\mathrm{N}=20)$ and negative $(\mathrm{N}=18)$ descriptions of Leader Smith's workday. At the beginning of the data collection situation, the students were informed about the researcher and the purpose of the research (see also Eskola, 1997). The data collection was successful and the students' essays were rich and informative.

The data were analyzed first with the method of the analysis of narratives (Polkinghorne, 1995; see also Heikkinen, 2010; Riessman, 2001). In the second round of analysis, the variation between the two kinds of stories were analyzed according to the idea of MEBS (Eskola, 2010). The purpose was to find elements of good leadership in the stories. The data were analyzed primarily as an entity. Thus, the main emphasis in this article is to introduce findings from the holistic analysis that was to provide a description of good leadership. The main changes resulting from the positive and negative frame stories will also be introduced accompanied by numbers of children having presented each theme in their narratives (e.g., descriptions of leaders' caring attitude).

When introducing the findings, excerpts from the essays are included to illustrate how students wrote about leaders. They are also to support and make visible the researchers' interpretations. Essays about the positive workday were coded randomly with numbers 1 to 
10, and the essays about negative workdays with letters a to $r$. In the Finnish language, there is no separate word for he and she, and therefore, it was not always clear whether students referred to a female or a male leader. In these cases, the translations in excerpts use just the word "Smith" or "Leader Smith" and when impossible to express without the personal pronoun, the expression "him/her" or "himself/herself" is used. When the student has used a word that reveals the gender he or she was thinking about, the translation follows that literally.

Research with children has many dimensions that present their own challenges for research (Clark, Flewitt, Hammersley, \& Robb, 2014; Uusiautti \& Määttä, 2013b). Still, these kinds of studies are often very interesting and provide new insights and viewpoints, too. Modern research, like the one at hand, emphasizes children as active and capable subjects (Bucknall, 2014; Fattore, Mason, \& Watson, 2012; Uusiautti \& Määttä, 2013a).

Ethical reflection is an important part of any research (see e.g., Keskitalo, Määttä, \& Uusiautti, 2012; Kvale, 1996), but especially when conducting research with children (see e.g., Alderson \& Morrow, 2011; Lagström, Pösö, Rutanen \& Vehkalahti, 2010; Uusiautti \& Määttä, 2013a). The crucial issue is to find and select methods that bring out children's voices the best without harming them in any way (Peltokorpi, Määttä, \& Uusiautti, 2013). The method of empathy-based stories seemed a suitable method because it allowed students to express their thoughts freely and anonymously. In addition, the data collection situation did not stress them or cause extra burden, because the data were obtained during a Finnish lesson. This was favorable also reliabilitywise because sometimes the authenticity of a writing situation can be questioned (Eskola \& Suoranta, 1998). Writing the stories during a Finnish lesson, it was easy make sure that everyone wrote their own stories and that no one influenced them.

One ethical issue in child research is to make sure that participation in research is voluntary (see e.g., Alderson \& Morrow, 2011; Lagström, Pösö, Rutanen \& Vehkalahti, 2010; Uusiautti \& Määttä, 2013a). In this study, permissions to participate in the research were obtained from the students' parents. In addition, students were informed that their participation is voluntary and that they could withdraw from the research at any point, and that their parents were aware of the research.

\section{Results}

\subsection{Characteristics of a Good Leader According to Finnish Sixth-Graders}

Next, we will introduce the characteristics of a good leader as the students described them. However, to help the reading of results, it is good to sum up how the students defined a leader. Half of the students $(\mathrm{N}=19)$ wrote that a leader is the chief executive officer of an enterprise. Six students specified that the enterprise was the leader's own. In the remaining half of the essays $(\mathrm{N}=19)$, the leader was working in different kinds of place varying from a bank to army and from a plant to a hospital (managing doctor). Three main characteristics emerged from the data to describe a good leader. They were friendliness, diligence and enthusiasm, and deliberation and determination. These features were described in positive stories as the 
virtues of a leader, and in negative stories as failed interaction or misbehaviors. Diligence and enthusiasm are represent a certain type of vigor at work, while deliberation and determination are characteristics that resemble merely an attitude or consideration of how to proceed, for example, in the direction of goals at work.

\subsubsection{Friendliness}

Thirteen students described friendliness in various ways when defining a good leader. Friendliness was illustrated, for example, as a happy leader who is in a good mood "Smith's cheerfulness was evident..." (Student 6) and generous action "The leader is noble-minded and wise and accepts most of the employees' ideas." (Student 9). In the analysis, joyfulness, conviviality, generousness, and similar positive features were seen as descriptions of friendliness.

It is noteworthy that several students mentioned that a good leader greets everyone they see whether the person was an employee or an important customer. In the stories, the leader was also rewarded for being friendly:

"Employees had decided to buy Smith a good present because Smith had been so friendly to them and a good leader. Employees liked Smith because Smith was so funny and nice." (Student 16)

The importance of friendliness was emphasized also in stories that described the negative workday. Altogether 13 students included descriptions of friendliness in their narratives. Of these, eight narratives were based on the positive and five on the negative frame story.

Some students wrote how the leader snapped and yelled at and were rude to employees. "In the grocery store, Smith gives orders rudely to the servile." (Student d) These kinds of narratives were analyzed as showing the features of an unfriendly leadership style, such as lack of empathy and distant relationships with employees. These notions support the finding of friendliness being an important feature of good leadership.

"Leader Smith was expecting a very hard and busy day at the gaming firm, and Smith was already stressed out. At the workplace, Smith snapped at others and the employees did not like it." (Student i)

\subsubsection{Diligence and enthusiasm}

The features of diligence and enthusiasm were found in 17 narratives. These were characteristics, that also showed the leader's commitment to work efficiently. "Smith finished many tasks even though there was time to do them in other days too." (Student13) According to students, a good leader tries to work quickly even if the schedule did not demand it.

The students' stories suggested that diligence itself increased satisfaction and sense of well-being in leaders. "In the evening, at home, Smith thought all that was done during the day, and was very happy." (Student 18). In addition to personal good feeling, the leader's diligence was noticed by others, too. One student wrote how the leader was awarded for being so industrious: "Smith had also been given an entrepreneurship medal that can be 
earned only by working pretty hard." (Student 1)

Diligence was also described as being in time at work and coming early. It was possible to interpret that the leader set an example to employees and inspired them by being such hard-working a leader. "Smith does not loaf around, and does not yell at others. Every day Smith comes to work early, and is never late for work." (Student 12)

However, students did not mention the problems of working too much and becoming stressed with the workload but merely the feelings of guilt if the leader had not worked as hard as was expected or he or she would have wanted to. "Smith spent a lot of time eating at the cafeteria and at stores in the city while other employees were working. Smith should have been working too but was just slacking at the city." (Student j) "However, Smith thought of being a bad leader because Smith had been late from work.” (Student 1)

Similarly, students described that a good leader is enthusiastic about work. This kind of enthusiasm was described as the leader being energetic, active, and spry. "Smith is downright bursting with energy." (Student 10) "At work, Leader Smith is always fresh and in a good mood." (Student 9) The leader's enthusiasm creates a positive atmosphere where a good work ethic prevail. Like in diligence, the leader can show example through enthusiasm, too: "Smith looks at cereals and gets an insight. Smith dashes to the office and starts designing a commercial. 'This will be brilliant', Smith thinks.” (Student 20)

\subsubsection{Deliberation and determination}

Altogether 13 students mentioned deliberation and determination as features of good leadership. The third set of a good leader's characteristics consists of deliberation and determination. "Smith is liked as a leader because Smith does everything properly and meticulously." (Student 13) Excessive specificity as a negative feature was not mentioned but six students wrote about the significance of deliberation in their narratives based on the negative frame work. For example, the following two students described well what would happen if the leader was hasty or careless. "Smith went off to the education place with full speed. There had been a small mistake, but to Smith it was a big one. The employee was sorry about it but Smith said: 'It is not your fault. It is totally my fault because I gave a wrong task to you."” (Student r) “...is not careful, is not punctual, and thus makes mistakes.” (Student b)

On the other hand, when students described the leader's workdays, good leaders seemed to learn from their mistakes. Indeed, the students wrote about how good leaders know themselves and admit and learn from their mistakes. Naturally, this was evident in essays that illustrated negative events during the workday. However, a good leader was reported to become aware of his or her behavior and reflect on reasons for it.

"Smith hangs on there until the end of the day and returns home being angry. Only at home Smith realizes having behaved wrongly. Overwhelming pressures and adversities had put Smith in a bad mood. Smith should change this attitude..." (Student d)

"Smith did self-reflection. How could this kind of a huge failure be possible even if Smith had years of education in leadership. Smith was also thinking about the reasons. Soon Smith 
notices that it had happened due to Smith's busyness. Smith did not even sleep last night. Luckily one can learn from one's mistakes!” (Student r)

The leader's determination was described in stories either directly or as various behaviors that illustrate determination. These were, for example, descriptions of the leader's courage to seize challenges and resolution. "Smith is a good leader because Smith is determined and hard-working. - - Smith can also be strict if things do not go as they should." (Student 11) According to our interpretations, determination was perceived as a good feature with which the leader could lead things. Determination was described mostly in those essays that were about positive workdays. Only one story about a leader's negative day mentioned lack of determination in the leader's action. "Leader Smith has always known to be proud and self-confident but now Smith is so bored with the work that nothing goes like planned. Smith used to be interested in this field but now something has happened." (Student k) Perhaps, determination and self-criticism had raised the leader's expectations about his or her performance too high. However, this was not discussed further in the students' narratives.

\subsection{Emphases in a Good Leader's Action According to Finnish Sixth-Graders}

When analyzing the essays for descriptions of leaders' action, some main categories could be found: caring, decision-making and responsibility for results, and enjoyment of the leader's work.

\subsubsection{Caring}

When analyzing emphases in leaders' work from the essay data, caring activities formed a category of its own. It included, however, many types of behaviors and activities that could be categorized as caring; for example, taking care of employees' well-being and basic matters, proper salaries, and nurturing. Caring was mentioned by the majority of students $(\mathrm{N}=22)$. Of these narratives, eight were based on the negative and 14 on the positive frame story. Several students described this kind of caring. "Smith has plenty of issues and employees to deal with. - - After careful deliberation, Smith decides to cut down the workload and promises to arrange a recreational theme day to employees. Employees end their strike and start working industriously again." (Student 8) The aforementioned excerpt shows that students were aware that leaders do not just manage but lead people, too. Therefore, it seemed that goal-orientation and determination did not exclude caring but these features could be present in a leader at the same time.

One of the caring activities described in essays was thanking. A good leader remembered to thank his or her employees, and based on the essays, it was the leader's task to do so. "Leader Smith noticed everyone and remembered to thank them for the work they had done. Previously, everyone had thought that Smith was a selfish leader who did not thank employees. Smith was satisfied because employees had done a great job and Smith had remembered to thank them." (Student 17)

Caring could be depicted as willingness to take care of the basic work conditions, such as giving an appropriate salary. Students wrote how important it was to get paid justly for the work done. This was mentioned not just regarding employees' salaries but also regarding the 
leader's paycheck. However, mostly the students discussed how a good leader is generous, while a bad one is not. "They were not satisfied with Mr. Smith because he gives too much work to his followers and pays too little." (Student 8) "Smith's followers have been a long time of the opinion that they would need better salaries and less work hours a week." (Student c)

Caring was also described as mutual respect. Those students who wrote about a positive workday mentioned respect or other similar concepts. "Employees respect Smith." (Student 11) "Salespersons (subordinates) had been praising the leadership method and how good a leader Smith was." (Student 10) Lack of respect was apparent in those essays where students had to explain why the leader's day had not been so good. "In the employees' opinion, Leader Smith was selfish and did not appreciate employees enough.” (Student k) "Leader Smith's followers were mad because Smith blamed them for what had happened. Some of them even wanted to quit and leave, because they felt not being appreciated. But luckily Leader Smith understood to apologize." (Student b) This example also shows how a caring leader learns from mistakes and can admit them.

Furthermore, caring could be manifested as daily helping, listening, and guiding, that were mentioned by 13 students. The theme was evident in both types of narratives ( $N=5$ based on the negative frame story and $\mathrm{N}=8$ on the positive frame story. "Leader Smith came home being frustrated and in a bad mood. Smith was wondering why all employees left, and realized that Smith had been a bad leader. Smith did not help others, spend time with employees, or solve conflicts between employees, and just let everything go on. Smith should have helped and advised others." (Student o) Listening and negotiating were important parts of a leader's work in the students' essays. Actually, by using these exact words, students showed that they understood the nature of a leader's work quite well. "First, Smith had a meeting with a few line managers and listened carefully to everyone's opinions, and took them into consideration." (Student 18) "First, Smith was hesitating. Smith would still want to negotiate about it with employees because they trust each other completely. Employees are satisfied with the suggestion. They encourage Smith to accept the offer. Smith goes back to office to think about the offer. Smith decides to accept it." (Student 14) This also shows how caring could not separate from leaders' goal-orientation.

Despite the caring purposes, the leader cannot always accept or fulfill employees' wishes (see e.g., Uusiautti, 2013) - this was noticed by students as well. Instead, they considered it more important that the leader listens and is willing to negotiate with the employees before making the decision. "They discuss long and intensively. The result is that the leader does not accept the employees' request. So, the employees start a strike...” (Student c)

\subsubsection{Decision-making and responsibility for results}

A half of the students $(\mathrm{N}=18)$ wrote that leaders had to make all kinds of decisions as a part of their work, such hiring new employees and delegating work tasks. "My workday had included all kinds of things, such as choosing the ones who get to work among newcomers." (Student 3) "Smith called everyone and explained the work plan." (Student 4) Treating employees evenly was not always easy, which was something that appeared difficult to 
children to describe in their narratives.

Some of the students wrote that leaders have to attend various meeting and pow-wows. Meetings and decision-making are quite typical elements of management, and therefore, it is understandable that students wrote about them the first in their essays. However, one student summed up well that being a leader is more than management. "The leader's role is more than distribute tasks. The leader is responsible for what the others do and how they act. The leader is a sort of a role model to other employees." (Student a) Several students reported that leaders are first-and-foremost role models. This was also connected with the responsibility for results and productivity: “...Smith had been thinking that why I am a good leader. Maybe because I have been doing all my tasks well.” (Student 6)

The students realized that being a leader is demanding. They described how leaders have to make sure that goals were met and sometimes leaders had to make difficult decisions.

"Smith had to make a difficult decision. The company is big and new orders are coming all the time, and items should be shipped to customers. The company has plenty of employees, so if their salaries are raised, capital of the company would decrease so much that Smith could not let employees have their leaves. On the other hand, if their tasks are cut, orders are not fulfilled, and the company will go bankrupt." (Student 8)

In addition to difficult decisions, leaders have to be goal-oriented even if employees did not accept it. The demanding position as a leader means responsibility for results.

"Smith goes to office and makes important work calls. Many unpleasant issues come out during the phone calls. A customer's big order becomes cancelled because the customer had found the same product with a better price. Smith tries to lower the price but cannot ask less because otherwise the deal would not be profitable." (Student d)

"Smith started to think about some changes in production because it was decreasing. - Employees had no worries whatsoever and production was slow, but Mr. Smith wanted production go up, not vice versa. Mr. Smith announced to employees that breaks would be shortened and they should work harder. Having said that Mr. Smith started to hear bellowing and some booing in the plant. When Mr. Smith was leaving home, employees passing him did not greet him and looked mad, some of them even eyeballed him.” (Student n)

The aforementioned except shows how leaders have to control and oversee work to meet the organizational goals. Other essays had also notes about controlling and monitoring of employees work. "When the work was done, it was Leader Smith's turn to come and check the quality. Looks great." (Student 4). Yet, too high expectations and inflexibility can be a leader's negative features and arouse resistance in employees.

\subsubsection{Enjoying the leader's work}

Interestingly, the students described that as a part of being a good leader, the leader should enjoy his or her work and find it self-fulfilling. Several students wrote about leaders' work satisfaction and joy of work. It was noteworthy that the joy of work was mentioned both in stories about negative workdays and positive ones. All essays that mentioned happiness, 
satisfaction, and contentment regarding working were categorized in the category of enjoying one's work as a leader. "One sunny day, the leader of the Felt Boot Factory Mr. Smith went to work. He liked his job and was happy." (Student n) "Leader Smith is really happy about the work outcomes and congratulates himself/herself for good work: going under the deadline, magnificent results, and happy employees. Smith goes home after a long but eventful workday and treats himself/herself to sauna and long sleep at night.” (Student 4)

Correspondingly, those essays that mentioned lack of joy at work were categorized in the category if enjoying one's work. "It is Monday and Leader Smith is going to work. Smith would not want to because Smith is uninterested about the work at the workplace that is specialized into selling and preparing electronic devices. 'I have been fixing computers and mobile phones for many years, and not interested anymore', Leader Smith is thinking.” (Student k). A leader's negative feature can be the inability to discuss with employees and being bored with the leader's own work.

Another aspect to enjoyment at work was the so-called path from difficulties to victory that was mentioned in several essays, negative and positive ones. "Usually, Smith did not work together with the personnel and someone did not like Smith. Now everyone had changed their minds and they thought that Leader Smith was the best leader in the world." (Student 17)

A path from difficulties to victory was interpreted to show enjoyment at work because the students described challenges and trouble the leaders had faced during their workday and how they eventually solved them. From the negative perspective, the leader may not always be able to prioritize his or her tasks or is too focused son duties of secondary importance. Also unpleasant coincident and issues that were not the leader's fault had their own role in these stories. These also can influence the level of joy of work and work satisfaction the leader experiences. However, it was the leader's attitude and determination to succeed in his or her work that showed whether the leader found the leader's work enjoyable or self-fulfilling.

"At home, Smith thought that this cannot go on. Smith considered himself/herself a bad leader because he/she had treated employees badly and had not taken care of all the meetings and discussions of the day well. Plus, Smith had forgotten to pay salaries yesterday, which had made employees especially angry. Leader Smith already considered changing job because Smith thought that no one really wanted him/her to become the leader. But then Smith straightened up and decided that tomorrow they would have a good atmosphere at work and that all would be good." (Student i)

\section{Discussion and Conclusion}

\subsection{Summary of the Results}

This study focused on Finnish sixth-graders' descriptions of a good leader. The essays depicted the leadership narratives of friendliness, diligence and enthusiasm, and deliberation and determination. These features can also be viewed from the perspective of authentic leadership (see e.g., Gardner et al., 2011; Gill \& Caza, 2015; Hyvärinen, Uusiautti, \& Määttä, 2015; Ladkin \& Taylor, 2010) and its four elements of self-awareness, relational transparency, 
balanced processing, and internalized moral perspective (see e.g., Avolio \& Gardner, 2005; Gardner et al., 2011; Gill \& Caza, 2015).

The first element of self-awareness includes the ability to recognize one's authentic influence on other people (see e.g., Avolio \& Gardner, 2005; Gardner et al., 2011; Gill \& Caza, 2015; Lewis, 2010; Northouse, 2013). This element was clearly present in the students' leadership narratives, especially in their descriptions of the leaders' friendliness and its importance. The narrative of friendliness can also be contrasted with the second element of authentic leadership, relational transparency, which refers to an appropriate way of expressing oneself and interacting with others. This could be interpreted also from those narratives that described the leaders' indiscreet behaviors (see also Avolio \& Gardner, 2005; Gardner et al., 2011; Gill \& Caza, 2015; Lewis, 2010; Northouse, 2013), because leaders should be aware of the meaning and influence of their behavior in the work community.

According to the students' opinions, a good leader is diligent and enthusiastic. When compared to the authentic leadership theory, diligence is a part of self-awareness because in leadership stories, hard-working leaders set the example for the whole workplace and all employees (see also Avolio \& Gardner, 2005; Gardner et al., 2011; Gill \& Caza, 2015; Lewis, 2010; Northouse, 2013). Setting a positive example, the leader could build a good image not only of himself or herself but also signal about the joy of working which was one of the most important emphases of leadership action in students' essays. Today's work indeed needs leaders who are willing and able to work hard, learn new and develop themselves (see Fleming, 2001; Niles, Amundson, \& Neault, 2011). Likewise, a majority of the current leadership theories emphasize that it is possible to learn, tailor, mold, and develop leadership (Syväjärvi \& Vakkala, 2012; Uusiautti et al., 2012). According to the students' descriptions, good leaders are also deliberate and determined which illustrate self-awareness and balanced processing of information in authentic leadership (Avolio \& Gardner, 2005; Gardner et al., 2011; Gill \& Caza, 2015; Lewis, 2010; Northouse, 2013).

The fourth dimension of authentic leadership is the internalized moral perspective (Avolio \& Gardner, 2005; Gardner et al., 2011; Gill \& Caza, 2015). This was evident especially in the students' descriptions of how leaders act and treat others. Although children did not specifically mention the word "moral", their stories can be interpreted from this perspective. Especially, in their descriptions of the ways the leaders made decisions and showed responsibility for outcomes and employees' well-being, the students included high-level moral reasoning as a part of a leader's work. While authentic leadership theory has been criticized for including the moral component as a part of authenticity (e.g., Shamir \& Eilam, 2005), it can be stated, that the moral perspective does include certain behaviors, such as honesty and integrity and ethical decision-making. They are moral values and cannot be showed otherwise but in action and in daily choices that the leaders make (Cianci, Hannah, Roberts, \& Tsakumis, 2014).

The second aspect of the study was to analyze the main emphases in leaders' action, and three main categories introduced as results were decision-making and responsibility for outcomes, caring, and enjoying the leader's work. As mentioned, these could be also positioned within 
the authentic leadership theory. Furthermore, several students wrote about overcoming adversities, the so-called path from difficulties to victory, in which the leaders solved problems and made decisions. Perseverance illustrated how leaders eventually enjoyed their work, learned from their mistakes, and set an example to others. This type of behavior can also be seen as resilience (see e.g., Luthar, Cicchetti, \& Becker, 2000; Tugade \& Fredrickson, 2004) which refers to one's ability to act constructively and develop after a crisis or an adversity. The ability of bouncing back means that one can tolerate difficulties and adversities and work determinedly for success (Luthans, 2002; Luthans et al., 2007). However, resilience is not just a feature or a trait but merely a dynamic process that makes positive adjustment possible (Rutter, 2008; see also Luthans, 2002). Likewise, Sparrowe (2005) noted that resilience is a part of authentic leadership that can be illustrated specifically with narratives.

\subsection{Toward Ideal Leadership}

When analyzing children's perceptions, it seemed that they included the elements of authentic leadership theory. On the one hand, children described ideal leaders but simultaneously, they reported various problematic situations that leaders may face and that could result from their shortcomings as leaders. It is noteworthy that even though the frame stories had the emphasis on a leader's work day and events taking place during it, the children still had a longer perspective in their stories which meant that the being a good or a bad leader could not be determined just based on one day's events: the good and bad events that made the leader happy or unhappy in stories either originated from a longer chain of events (e.g. Smith had been always working hard) or had a far-reaching future perspective (e.g., Smith would remember to thank employees from now on).

Yet, the features of a good leader are something that each leader could use as their guidelines in their work and development as leaders. Therefore, it might be relevant to ask whether the essence of ideal leadership emerges when the characteristics of a good leader (friendliness, diligence and enthusiasm, and deliberation and determination) converge with the emphases of a good leader's leadership action (decision-making and responsibility for outcomes, caring, and enjoying the leader's work). In a wider sense, it is a sum of several factors and, thus, ideal leadership is downright impossible to sum up. Still, one can wonder if these schoolchildren were able to crystallize the essence of ideal leadership in their essays. At least, these future leaders apparently realized that development as a leader requires successes and positive development in many levels.

The process of becoming a good leader can be seen as a process that manifests positive development (Uusiautti \& Määttä, 2013c). According to some studies (Hyvärinen, 2016; Murphy \& Johnson, 2011), leadership development begins already in childhood. This kind of life-span perspective emphasizes early developmental factors in the emerging leader identity in children (Lord \& Hall, 2005; Murphy \& Johnson, 2011). The process of developing as a leader is demanding, and still no leader is flawless. This was also noticed in the students' essays where the leaders admitted and learned from their mistakes. Thus, good leadership is human without expectations of being a perfect leader or human being.

As the research participants in this study were students, it is also interesting to discuss what 
kinds of models and opportunities school provides for leadership development. First of all, school personnel, principles and teachers, set an example of leaders at school. For example, Witziers, Bosker and Krüger (2003) concluded that the principal's leadership style has an influence on children and their school achievements (see also Dinham \& Scott, 2007; Waters, Marzano, \& McNulty, 2004). School administration creates the atmosphere and climate at the school level (e.g., Uusiautti, 2012), while teachers show their leadership in creating a positive learning environment in classrooms showing also example of self-leadership (Leskisenoja, 2016; Määttä \& Uusiautti, 2012). Although leadership in education may differ from the enterprise leadership, the new perspectives of leadership do include features (e.g., strengths-based approaches and caring) that are usable and applicable in both contexts and likely lead to improved performances and flourishing alongside well-being (see e.g., Quinn, 2015).

In addition, leadership can be practiced in daily practices if encouraged, supported and spurred (Murphy \& Johnson, 2011). In today's school environment, it means little actions that supports development toward leadership in those that may find it self-fulfilling, but the principles of nourishing diligence, empathy and caring, teamwork, and bearing responsibility are good characteristics in everyone. They are also everything that the students in this study connected with good leadership. Actually, even the new national core curriculum for basic schools in Finland (2014) aims to emphasize new kinds of work and entrepreneurship skills.

In this sense, also the viewpoint of enjoying the leader's work as presented in the students' essays is extremely interesting. As the new curriculum emphasizes the joy of learning bringing out the importance of good work attitude, it is relevant to focus on students strengths and encourage them to find ways they feel they are fulfil themselves. Finding job that allows one use one's strengths and find meaning in life (see also Uusiautti \& Määttä, 2015) is something everyone should be vouchsafed. The students' stories showed that work as a leader and succeeding in it also necessitates that leadership is one's strength (see e.g., Seligman, 2011).

From the perspective of school leadership, the new curriculum also emphasizes shared leadership. It is reasonable to ask how leadership appears in the way a positive atmosphere is created in school and in classrooms, the way students' strengths, creativity, and abilities are noticed in schools, and the way mutual support and positive interaction is supported in schools.

\section{References}

Alderson, P., \& Morrow, V. (2011). The ethics of research with children and young people: a practical handbook. London: Sage. https://doi.org/10.4135/9781446268377

Allen, J. P., Hauser, S. T., Bell, K. L., \& O’Connor, T. G. (1994). Longitudinal assessment of autonomy and relatedness in adolescent-family interactions as predictors of adolescent egodevelopment and self-esteem. Child Development, 65, 179-194. https://doi.org/10.2307/1131374

Aubrey, J. S., \& Harrison, K. (2004). The gender-role content of children's favorite television 
programs and its links to their gender-related perceptions. Media Psychology, 6(2), 111-146. https://doi.org/10.1207/s1532785xmep0602_1

Avolio, B. J., \& Gardner, W. L. (2005). Authentic leadership development: Getting to the root of positive forms of leadership. The Leadership Quarterly, 16, 315-338. https://doi.org/10.1016/j.leaqua.2005.03.001

Berscheid, E. (2002). Relationships with others: The human's greatest strength. In L. G. Aspinwall \& U. M. Staudinger (Eds.), A psychology of human strengths: Perspectives on an emerging field (pp. 37-47). Washington, DC: APA.

Bigler, R. S., Arthur, A. E., Hughes, J. M., \& Patterson, M. M. (2008). The politics of race and gender: children's perceptions of discrimination and the U.S. presidency. Analyses of Social Issues and Public Policy, 8(1), 83-112. https://doi.org/10.1111/j.1530-2415.2008.00161.x

Bradley, R. H., \& Corwyn, R. F. (2002). Socioeconomic status and child development. Annual Review of Psychology, 37, 399. https://doi.org/10.1146/annurev.psych.53.100901.135233

Bruner, J. (1986). Actual minds, possible worlds. Cambridge, MA: Harvard University Press.

Bruner, J. (1987). Life as narrative. Social Research, 54(2), 11-32.

Bruner, J. (1991). The narrative construction of reality. Critical Inquiry, 18(1), 1-21. https://doi.org/10.1086/448619

Bucknall, S. (2014). Doing qualitative research with children and young people. In A. Clark, R. Flewitt, M. Hammersley, \& M. Robb (Eds.), Understanding research with children and young people (pp. 69-84). London: Sage.

Busser, C. (2015). Having or being a good boss. In S. J. Lopez, J. Teramoto Pedrotti, \& C. R. Snyder (Eds.), Positive psychology. The scientific and practical explorations of human strengths (pp. 433-435). Los Angeles, CA: Sage.

Cianci, A. M., Hannah, S. T., Roberts, R. B., \& Tsakumis, G. T. (2014). The effects of authentic leadership on followers' ethical decision-making in the face of temptation: An experimental study. The Leadership Quarterly, 25, 581-594. https://doi.org/10.1016/j.leaqua.2013.12.001

Clark, A., Flewitt, R., Hammersley, M., \& Robb, M. (Eds.) (2014). Understanding research with children and young people. London: Sage.

Dinham, S., \& Scott, C. (2007). Parenting, teaching and leadership styles. Australian Educational Leader, 29(1), 30-32, 45.

Dodge, J., Ospina, S. M., \& Foldy, E. G. (2005). Integrating rigor and relevance in public administration scholarship: The contribution of narrative inquiry. Public Administration Review, 65(3), 286-300. https://doi.org/10.1111/j.1540-6210.2005.00454.x 
Engel, S. (1995). The stories children tell. Making sense of the narratives of childhood. Gordonsville, VA: W. H. Freeman and Company.

Eskola, J. (1997). Eläytymismenetelmäopas [Manual of method of empathy-based stories]. Tampere: TAJU.

Eskola, J. (1998). Eläytymismenetelmä sosiaalitutkimuksen tiedonhankintamenetelmänä [The method of empathy-based stories as the data collection method in social research]. ( $\mathrm{PhD}$ diss., University of Kuopio, Finland.)

Eskola, J. (2010). Eläytymismenetelmän autuus ja kurjuus [The beauty and misery of the method of empathy-based stories]. In J. Aaltola, \& V. Raine (Eds.), Ikkunoita tutkimusmetodeihin I. Metodin valinta ja aineistonkeruu: virikkeitä aloittelevalle tutkijalle [Viewpoints to research methods I. Choosing a method and data collection: ideas for beginning researchers] (pp. 72-87). Jyväskylä: PS-kustannus.

Eskola, J., \& Suoranta, J. (1998). Johdatus laadulliseen tutkimukseen [Introduction to qualitative research]. Tampere: Vastapaino.

Fattore, T., Mason, J., \& Watson, E. (2012). Locating the child centrally as subject in research: towards a child interpretation of well-being. Child Indicators Research, 5(3), 423-435. https://doi.org/10.1007/s12187-012-9150-x

Fleming, D. (2001). Narrative leadership: Using the power of stories. Strategy \& Leadership, 29(4), 34-36. https://doi.org/10.1108/s1.2001.26129dab.002

Gardner, W. L., Cogliser, C. C., Davis, K. M., \& Dickens, M. P. (2011). Authentic leadership: A review of the literature and research agenda. The Leadership Quarterly, 22, 1120-1145. https://doi.org/10.1016/j.leaqua.2011.09.007

Gill, C., \& Casa, A. (2015). An investigation of authentic leadership's individual and group influences on follower responses. Journal of Management, published online before print Jan 15. https://doi.org/10.1177/0149206314566461

Hallinger, P., \& Heck, R. H. (2011). Collaborative leadership and school improvement: understanding the impact on school capacity and student learning. In T. Townsend \& J. MacBeath (Eds.), International handbook of leadership for learning (pp. 469-485). Dordrecht: Springer. https://doi.org/10.1007/978-94-007-1350-5_27

Hannah, S. T., Avolio, B. J., \& Walumbwa, F. O. (2014). Addendum to "Relationships between authentic leadership, moral courage, and ethical and pro-social behaviors". Business Ethics Quarterly, 24(2), 277-279. https://doi.org/10.5840/beq201453011

Harter, S. (2002). Authenticity. In C. S. Snyder, \& S. J. Lopez (Eds.), Handbook of positive psychology (pp. 382-394). Oxford: Oxford University Press.

Hartman, S. J., \& Harris, O. J. (1992). The role of parental influence in leadership. Journal of Social Psychology, 132(2), 153-167. https://doi.org/10.1080/00224545.1992.9922968

Heikkinen, H. L. T. (2010). Narratiivinen tutkimus - todellisuus kertomuksena [Narrative 
research - reality as a narrative]. In J. Aaltola \& R. Valli (Eds.), Ikkunoita tutkimusmetodeihin. Näkökulmia aloittelevalle tutkijalle tutkimuksen teoreettisiin lähtökohtiin ja analyysimenetelmiin [Viewpoints to research methods. Ideas to beginning researchers to theoretical framework and analyzing methods] (pp. 143-159). Jyväskylä: PS-kustannus.

Hoffner, C. (1996). Children's wishful identification and parasocial interaction with favorite television characters. Journal of Broadcasting and Electronic Media, 40(3), 389-402. https://doi.org/10.1080/08838159609364360

Hyvärinen, S. (2016). Monta polkua johtajuuteen: naisjohtajien urakertomuksia [Many paths to leadership - female leaders' career narratives]. (PhD Diss., University of Lapland, Finland.)

Hyvärinen, S., \& Uusiautti, S. (2014). Safe and encouraging home providing the countdown to leadership? Finnish female leaders' childhood memories. Early Child Development and Care, 184(11), 1723-1740. https://doi.org/10.1080/03004430.2013.876626

Hyvärinen, S., Uusiautti, S., \& Määttä, K. (2014). Having many irons in the fire - Finnish Female leaders' school memories. Journal of Education and Learning, 3(2), 1-13. https://doi.org/10.5539/jel.v3n2p1

Hyvärinen, S., Uusiautti, S., \& Määttä, K. (2015). "I do not let setbacks discourage me much" The composition of a Finnish female leader. Journal of Educational and Developmental Psychology 5(2), 14-27. https://doi.org/10.5539/jedp.v5n2p14

Hänninen, V. (2000). Sisäinen tarina, elämä ja muutos [Inner narrative, life, and change]. (PhD Diss., University of Tampere, Finland.)

Ikonen, M. (2013). Trust development and dynamics at dyadic level: a narrative approach to studying processes of interpersonal trust in leader-follower relationships. (PhD Diss., University of Eastern Finland, Finland.)

Keskitalo, P., Määttä, K., \& Uusiautti, S. (2012). Ethical perspectives on Sámi school research. International Journal of Education, 4(4), 267-283. https://doi.org/10.5296/ije.v4i4.2908

Kvale, S. (1996). Interviews: an introduction to qualitative research interviewing. Thousand Oaks CA: Sage.

Kyrönlampi T., Uusiautti, S., \& Määttä, K. (2014). What is after-school childhood like? Children's descriptions of their daily rhythms. International Journal of Research in Studies in Education, 3(3), 49-66. https://doi.org/10.5861/ijrse.2014.704

Ladkin, D. (2010). Rethinking leadership. A new look at old leadership questions. Northampton, MA: Edward Elgar. https://doi.org/10.4337/9781849805346

Ladkin, D., \& Taylor, S. S. (2010). Enacting the "true self": Towards a theory of embodied authentic leadership. The Leadership Quarterly, 21, 64-74. https://doi.org/10.1016/j.leaqua.2009.10.005 
Lagström, H., Pösö, T., Rutanen, N., \& Vehkalahti, K. (Eds.) (2010). Lasten ja nuorten tutkimuksen etiikka [The ethics of researching children and youth]. Helsinki: Nuorisotutkimusverkosto.

Leskisenoja, L. (2016). Vuosi koulua-vuosi iloa. PERMA-teoriaan pohjautuvat luokkakäytänteet kouluilon edistäjinä [Year of school, year of joy - PERMA-based classroom practices enhancing perceived joy at school]. Rovaniemi: Lapland University Press.

Lewis, S. (2010). Positive psychology at work: How positive leadership and appreciative inquiry create inspiring organizations. Malden, MA: Wiley-Blackwell.

Li, Y., Anderson, R. C., Nguyen-Jahiel, K., Dong, T., Archodidou, A., Kim, I-H., Kuo, L-J., Clark, A-M., Wu, X., Jadallah, M., \& Miller, B. (2007). Emergent leadership in children's discussion groups. Cognition and Instruction, 25(1), 75-111. https://doi.org/10.1080/07370000709336703

Lieblich, A., Tuval-Mashiach, R., \& Zilber, T. (1998). Narrative research: Reading, analysis and interpretation. Thousand Oaks, CA: Sage. https://doi.org/10.4135/9781412985253

Lord, R. G., \& Hall, R. J. (2005). Identity, deep structure and the development of leadership skill. The Leadership Quarterly, 16(4), 591-615. https://doi.org/10.1016/j.leaqua.2005.06.003

Luthans, F. (2002). The need for and meaning of positive organizational behavior. Journal of Organizational Behavior, 23, 695-706. https://doi.org/10.1002/job.165

Luthans, F., Avolio, B. J., Avey, J. B., \& Norman, S. M. (2007). Positive psychological capital: Measurement and relationship with performance and satisfaction. Personnel Psychology, 60, 541-572. https://doi.org/10.1111/j.1744-6570.2007.00083.x

Luthar, S. S., Cicchetti, D., \& Becker, B. (2000). The construct of resilience: A critical evaluation and guidelines for future work. Child Development, 71(3), 543-562. https://doi.org/10.1111/1467-8624.00164

Madsen, S. R. (2007). Learning to lead in higher education: insights into the family backgrounds of women university presidents. Journal of Women in Educational Leadership, 5(3), 183-200.

Mahon, A., Glendinning, C., Clarke, K., \& Craig, G. (1996). Researching children: methods $\begin{array}{lllll}\text { and ethics. } \quad \text { Children } \quad \& \quad \text { Society, } & 10(2), & 145-154 .\end{array}$ https://doi.org/10.1002/(SICI)1099-0860(199606)10:2<145::AID-CHI19>3.0.CO;2-H

Murphy, S. E., \& Johnson, S. K. (2011). The benefits of a long-lens approach to leader development: Understanding the seeds of leadership. The Leadership Quarterly, 22(3), 459-470. https://doi.org/10.1016/j.leaqua.2011.04.004

Määttä, K., \& Uusiautti, S. (2012). Pedagogical authority and pedagogical love - connected or incompatible? International Journal of Whole Schooling, 8(1), 21-39.

Niles, S. G., Amundson, N. E., \& Neault, R. A. (2011). Career flow. A hope-centered approach to career development. Boston, MA: Pearson Education. 
Northouse, P. G. (2013). Leadership: Theory and practice. Thousand Oaks, CA: Sage.

Nyberg, D. \& Sveningsson, S. (2014). Paradoxes of authentic leadership: leader identity struggles. Leadership, 10(4), 437-455. https://doi.org/10.1177/1742715013504425

Peele, G. (2005). Leadership and politics: a case for a closer relationship? Leadership, 1(2), 187-204. https://doi.org/10.1177/1742715005051858

Peltokorpi, E-L., Määttä, K., \& Uusiautti, S. (2013). How to ensure ethicality of action research in the classroom? In S. Uusiautti, \& K. Määttä (Eds.), How to study children? Methodological solutions of childhood research (pp. 29-50). Rovaniemi: Lapland University Press.

Perusopetuksen opetussuunnitelman perusteet [National core curriculum for basic education]. (2014). Helsinki: Finnish National Boarch of Education.

Polkinghorne, D. E. (1995). Narrative configuration in qualitative analysis. In J. A. Hatch, \& R. Wisniewski (Eds.), Life history and narrative (pp. 5-23). London: Falmer Press. https://doi.org/10.1080/0951839950080103

Quinn, R. E. (2015). The positive organization. Oakland, CA: Berrett-Koehler. https://doi.org/10.5848/BK.978-1-62656-563-0_3

Riessman, C. K. (2001). Analysis of personal narratives. In J. F. Gubrium, \& J. A. Holstein (Eds.), Handbook of interview research: Context \& method (pp. 695-710). Thousands Oaks, CA: Sage.

Riessman, C. K. (2008). Narrative methods for the human sciences. Los Angeles, CA: Sage.

Russell, R. F., \& Stone, A. G. (2002). A review of servant leadership attributes: Developing a practical model. Leadership in Organization Development Journal, 23, 145-157. https://doi.org/10.1108/01437730210424

Rutter, M. (2008). Developing concepts in developmental psychopathology. In J. J. Hudziak (Ed.), Developmental psychopathology and wellness: Genetic and environmental influences (3-22). Washington, DC: APA.

Seligman, M. E. P. (2011). Flourish. A visionary new understanding of happiness and well-being. New York, NY: FreePress.

Seligman, M. E. P., Steen, T. A., Park, N., \& Peterson, C. (2005). Positive psychology progress. Empirical validation of interventions. American Psychologist, 60(5), 410-421. https://doi.org/10.1037/0003-066X.60.5.410

Shamir, B., \& Eilam, G. (2005). What's your story? A life-stories approach to authentic leadership development. The Leadership Quarterly, 16, 395-417. https://doi.org/10.1016/j.leaqua.2005.03.005

Sparrowe, R. T. (2005). Authentic leadership and the narrative self. The Leadership Quarterly, 16, 419-439. https://doi.org/10.1016/j.leaqua.2005.03.004 
Syväjärvi, A., \& Vakkala, H. (2012). Psykologinen johtamisorientaatio-positiivisuuden merkitys ihmisten johtamisessa [Psychological leadership orientation-the meaning of positivity in people management]. In J. Perttula, \& A. Syväjärvi (Eds.), Johtamisen psykologia-Ihmisten johtaminen muuttuvassa työelämässä [Psychology of leadership-People management in changing working life] (pp. 195-226). Jyväskylä: PS-kustannus.

Tugade, M. M., \& Fredrickson, B. L. (2004). Resilient individuals use positive emotions to bounce back from negative emotional experiences. Journal of Personality and Social Psychology, 86, 320-333. https://doi.org/10.1037/0022-3514.86.2.320

Uusiautti, S. (2013). An action-oriented perspective on caring leadership: a qualitative study of higher education administrators' positive leadership experiences. International Journal of Leadership in Education: Theory and Practice, 16(4), 482-496. https://doi.org/10.1080/13603124.2013.770077

Uusiautti, S., \& Määttä, K. (Eds.) (2013a). How to study children? Methodological solutions of childhood research. Rovaniemi: Lapland University Press.

Uusiautti, S., \& Määttä, K. (2013b). Many dimensions of child research. In S. Uusiautti, \& K. Määttä (Eds.), How to study children? Methodological solutions of childhood research (pp. 11-27). Rovaniemi: Lapland University Press.

Uusiautti, S., \& Määttä, K. (2013c). How to promote the healthy development of human resources in children and youngsters? In K. Määttä, \& S. Uusiautti (Eds.), Time for health education (pp. 131-140). Frankfurt am Main: Peter Lang.

Uusiautti, S., \& Määttä, K. (2015). The psychology of becoming a successful worker. Research on the changing nature of achievement at work. New York, NY: Routledge.

Uusiautti, S., Syväjärvi, A., Stenvall, J., Perttula, J., \& Määttä, K. (2012). “It’s more like a growth process than a bunch of answers" University leaders describe themselves as leaders. $\begin{array}{llll}\text { Procedia-Social and Behavioral } \quad \text { Sciences, } & 69,\end{array}$ https://doi.org/10.1016/j.sbspro.2012.12.005

Waters. T., Marzano, R., \& McNulty, B. (2004). Leadership that sparks learning. Educational Leadership, 61(7), 48-52.

Witziers, B., Bosker, R. J., \& Krüger, M. L. (2003). Educational leadership and student achievement: the elusive search for an association. Educational Leadership Quarterly, 39(3), 398-425. https://doi.org/10.1177/0013161X03253411

Yukl, G. (2010). Leadership in organizations. Upper Saddle River, NJ: Prentice-Hall.

\section{Copyright Disclaimer}

Copyright for this article is retained by the author(s), with first publication rights granted to the journal.

This is an open-access article distributed under the terms and conditions of the Creative Commons Attribution license (http://creativecommons.org/licenses/by/3.0/). 